\title{
Investigation of the Work Motivation Levels of Primary School Teachers*
}

\author{
Hatice Kadioğlu Ateş ${ }^{1}$, Perihan Yilmaz ${ }^{2}$ \\ ${ }^{1}$ Asistant Proffessor, Turkey, Sabahattin Zaim University, Turkey \\ ${ }^{2}$ Teacher, Turkey, MEB \\ Correspondence: Hatice Kadioğlu Ateş, Asistant Proffessor, Turkey, Sabahattin Zaim University, Turkey.
}

Received: January 24, 2018

doi:10.11114/jets.v6i3.2948

\author{
Accepted: February 23, 2018 \\ Online Published: February 25, 2018 \\ URL: https://doi.org/10.11114/jets.v6i3.2948
}

\begin{abstract}
This study was conducted to examine the work motivation levels of primary school teachers working in primary school institutions located in Istanbul province, Kucukcekmece district. The descriptive survey model was used in this study. The population of the study consists of primary school teachers and primary school administrators working in state primary school institutions that are affiliated to the Ministry of National Education in Kucukcekmece district. The sample of the study consisted of 343 primary school teachers and 28 primary school administrators that were selected using the disproportionate element sampling method from 14 state primary schools among the primary school institutions located in Kucukcekmece district. The "Work Motivation Scale" was used in order to collect data in the study. The Cronbach's alpha reliability coefficient of the work motivation scale was calculated as 0.897 in this study. SPSS 20.0 package software was used in the study. The average of the scores obtained by primary school teachers from the work motivation scale is $\bar{X}=$ 41.84, and the standard deviation is 10.32. The scores that can be obtained from the scale are between 18 and 90 . Accordingly, scores between 18 and 42 were interpreted as the low level of motivation, scores between 43 and 66 were interpreted as the intermediate level of motivation, and scores between 67 and 90 were interpreted as the high level of motivation. In general, it can be said that the work motivation of primary school teachers is low. The average work motivation scores do not vary by gender, age and marital status.
\end{abstract}

Keywords: work motivation, primary school teacher, primary school

\section{Introduction}

The fact that education has the most important contribution to the development of a country is widely accepted (Ozdemir, Yalin and Sezgin, 2008). Education is important for shaping the society (Celik and Gomleksiz, 2000). The place and importance of schools within the education system, which is an important factor in taking societies from past to present, and from present to future, are indisputable. Schools are places where educational activities are held. The efficiency of schools is subject to their good management (Ada and Baysal, 2012). The opinion that schools make up the most important part of the process of education is a widely accepted fact in Turkey and around the world (Fidan, 2012). The education-school administrator and teachers should exhibit effective behaviours in order for innovations to be created in the education system (Can, 2013). The success of the system is closely related to the success of the educator (Unal and Ada, 1999).

Nowadays, each society has prioritized raising individuals who protect their own culture and who are tolerant, productive, modern and have the highest level of social consciousness with the idea that suits the scientific norms over any other policy for its future, and has arranged the education system accordingly (Sulak, 2012). Teachers ensure the development of a country and raising qualified citizens (Celikten, Sanal and Yeni, 2005). A school is an environment of learning. A school is a social environment. A school is a working area if it can ensure that teachers create positive attitudes (Ultanır, 2007). A school is a place where the school administrator, teachers and students spend most of their time. Therefore, a school is an environment of socialization for these individuals (Ozdemir, 2015). Schools must create an effective

*This study was derived from the master's thesis entitled "Examination of the Work Motivation Levels of Primary School Teaches and Administrators" conducted by the second author in consultation with the first author at Istanbul Sabahattin Zaim University Institute of Social Sciences. It was presented as a verbal statement at the 3rd International Congress on Afro-Eurasian Research held in Istanbul on 19-21 October 2017. 
communication network to fulfil their aims. Schools must have an effective communication policy to be effective (Gunes, 2016). Teaching is a profession that requires expertise. The social status and respectability of the profession are also related to the knowledge, skills, competence and expertise of teachers. The levels of teachers' commitment to the school organization and their profession may increase in a teaching profession in which specialization is attached more importance, encouraged and rewarded (Sezgin, 2013).

Teachers are responsible for structuring an effective classroom climate in order for effective communication to take place (Aydin, 2004). It is necessary for all the employees in the organization do more than their duties willingly in order to increase the impact area of schools (Terzi and Kurt, 2005). The main element of arrangements for the education of human beings is the teacher. It is clear that raising qualified people is only possible with teachers with high qualities (Sulak, 2012). Each teacher who has taken an oath committing himself/herself to the values of teaching should be a principled and conscientious guide in the society as a human and as a teacher (Gungor, 2016). The motivation of teachers affects their working efficiently and willingly (Ates, Yildiz and Yildiz; 2012). The factors that motivate teachers and reduce their motivation should be paid attention, and teachers must be provided with the opportunities to work in a happy, peaceful and eager way in their education environments by taking these factors into account (Tas, 2005). The duty of taking the motivation of teachers to the top level primarily falls to the administrator (Karakose and Kocabas, 2006).

Motivation is a power that drives individuals for a certain aim, encourages them to work and increases the willingness to work in people. Managers who want to motivate their employees should especially be aware of personal differences, give feedback on the targets achieved, encourage participation in the decision, associate the rewards with performance, and review the fairness of the system. Economic rewards are important, but money is not everything. Appreciating the success is the way of motivating with the lowest cost. It should be noted that ingenuity is subject to compliments (Donmez, 2013). The school principal can show his/her formal effects by fulfilling one's written duties and responsibilities, performing the administrative tasks on time and adequately, providing the school's facilities to teachers, behaving in a fair and balanced way, rewarding the teachers who deserve it orally and in writing, i.e., by fulfilling his/her formal duties. By demonstrating the necessities of cooperation and team spirit, exhibiting democratic behaviours, creating an environment of mutual trust, and developing adopting, supportive and informal relationships in a sense, they will be able to make teachers and other employees feel their effect on them. Such effects and incentives will primarily positively support the performance of teachers (Can, 2013).

Motivation means the power that drives people to act for various aims (Eren, 2010). It basically means an impellent. Motivating means providing an individual with the incentive and motive for performing any act. Motivation is a summary of all factors that mobilize an individual (Adair, 2013). Motivation is a subject that concerns the employees and managers of any organization (Donmez, 2013). Motivation increases the productivity of an employee. The fact that the organization motivates its employees ensures providing high-quality service (Aydin, 2011). Work motivation means psychological processes that affect the behaviours of an individual. The consequences of work motivation are complex since there are many organizational and environmental factors that affect these psychological processes (Bennell and Akyeampong, 2007). These are processes that drive, guide and encourage an individual to work in order to achieve a particular aim and increase the concentration and willingness to work in individuals (Robbins, 2000).

It is important to increase the motivation levels of teachers (Yalcin and Korkmaz, 2013). Motivation is the key to a successful life. A motivated person considers problems as opportunities for development (Shinn, 2010). Motivation is based on fulfilling the needs (Hanks, 1999). The fact that school administrators try to solve their problems by monitoring the requirements of teachers in organizations will increase the quality of education, and therefore success (Gokay and Ozdemir, 2010). According to a study conducted abroad, especially young teachers who are new in the profession are not satisfied with their income. According to the researcher, payment incentives should be taken into consideration as a tool for increasing the motivation of teachers (Bishay, 1996). If the raw material of education institutions is human, teachers may cause problems in students when they are not fully motivated (Arslan, 2012). Motivation is among the most important factors that will affect the performance of teachers (Yavuz and Karadeniz, 2009). Job satisfaction and motivation are very important for the development of education. These elements that are indispensable in the lives of teachers make up the main reason for the study (Ololube, 2005).

The motivation of the teacher affects almost any factor related to the teacher in the school system (Tecer, 2011). It is known that the motivation levels of teachers are lower than those in other professions (Kurt, 2005). The number of studies on which incentives are found important by teachers is quite low (Cemaloglu, 2002). It is known that occupational motivation is associated with various factors that affect the working life (Unsar, 2011). Considering the negativities of giving the same reward to people who do their job well in the organization and others shows the importance of motivation (Gokay and Ozdemir, 2010). The more productive teachers are, the more motivated they are (Ayaydin and Tok, 2015). Managers should ensure that the sources are used in the most effective and efficient way with motivation (Genc, 2005). 
Motivation is of vital importance for individual and institutional performance, and even skilled and well-educated staff will not exhibit an efficient performance if they are not motivated (Addison and Brundrett, 2008). Teachers listed the factors that are necessary to increase the motivation of teachers as follows: "financial, incentive/promotion, time management, reward/appreciation, proper training, multiple duties, lack of authority and internal motivation were defined as the main motivation-reducing elements. Financial rewards, appreciation of the head of department and school administrator, certificate (medal) for special services, good working environment, providing assurance and supporting by including in decision-making processes were put forth as the most basic improving solutions" (Shukr, Qamar and Hassan, 2016). The motivation system developed for the performance of teachers at primary schools consists of six sub-systems, these are job-based motivation, reward-based motivation, good communication, establishing institutional relationships, working environment and the suitability of the working environment (Pasathang, Tesaputa and Sataphonwong, 2016). Motivation is the activation of the inner energy of individuals to guide them towards specific objectives (Duren, 2000).

School administrators must use the tools of motivation to achieve the required level of success. An effective, interactive, efficient and qualified school environment is created in this way (Yilmaz and Ceylan, 2011).

According to the opinions of primary school teachers, the elements that positively affect their motivation include organizational harmony, school culture and the personality traits of managers (being virtuous, adopting ethical principles). The fact that managers have high managerial qualities, i.e. they take initiatives, do not use only their own emotions and thoughts as a decision-making mechanism, and attach importance to the suggestions of teachers increase the work motivation of primary school teachers. According to the opinions of primary school teachers, the factors that negatively affect work motivation are an atmosphere of competition-gossip among teachers, the absence of work, activity, material, information sharing, the unfair criticism of activities such as year-end events, fest celebrations, etc., distributing the rewards to teachers who open an exhibition/perform a year-end show/activity, and perform visual activities, favouritism and discrimination. Primary school teachers stated that they are discriminated by gender, acquaintances, fellow citizenship, and spouse of the manager. Other organization-centered factors that reduce work motivation are the fact that the personality traits of the manager are not suitable for managing, acting as if he/she is the owner of the school and all employees are his/her slaves rather than only being the administrator of the school, the fact that audits are not conducted in a healthy and objective way, the management tries to establish the superior-subordinate relationship in an authoritarian manner, rudeness in the talking style when giving/distributing tasks, discouraging behaviours, offending teachers in the society, reprimanding them like a student, making face, inappropriateness in the conversational style, lack of the school culture (Cerit, Kadioglu Ates and Yilmaz, 2017). The fact that primary school teachers that are managed with non-ethical behaviours, with an authoritarian, repressive attitude also have low motivation is also an unexpected result.

The research results show that there is authoritarian management at schools in Turkey. However, the management style that seems to be the most suitable for the nature of schools is the supportive management style (Cicek Saglam, 2015).

Providing the physical conditions that will support cooperation and positive relationships between colleagues and improving the human capacity can be regarded as pre-conditions in turning the vocational education societies that act on the axis of learning and student in an effective school (Kilinc and Ogdem, 2013).

In another study conducted, primary school teachers stated that they are discriminated based on their syndicate, gender, hometown and political views, etc. A primary school teacher talks about an incident he/she has experienced in relation to favouritism as follows: "The principal and head deputy manager of the school where I worked were the representatives of a syndicate. One day, they called me when I was at the lesson, handed me a file, and told me to sign it. The file was the file of the syndicate. They said, "we are all from this syndicate. People from other syndicates are not accepted here." They caused no problem after that signature. They were clearly favouring people from their syndicate. Those who were given a certificate of achievement and rewarded through wage were also from that syndicate. No one objected to it." (Kadioglu Ates and Tinaztepe, 2016). The fact that primary school teachers managed with unethical behaviours, authoritarian and oppressive attitudes have low motivation is an expected result.

In the 21 st century, when the element of competition came into prominence, concepts such as productivity, performance and quality started to become important in contemporary organizations, and schools started to become affected by this situation. In this process, it is believed that a positive school culture and climate are important for schools to fulfil their aims effectively by playing an active part (Buluc, 2013).

The duty of the manager is to keep the organization alive according to its aims (Bursalioglu, 2014). Schools may keep up with the pace of the modern world only by being able to direct the change correctly. The speed and quality of this change are shaped according to many factors. The fact that schools are effective is primarily under the responsibility of school principals. A school principal is a leader first of all (Oklay, 2016). School administrators and teachers must be ethical and moral leaders as role model individuals. Therefore, school administrators must have the administrative and 
professional ethics and values system in the first place (Gungor, 2016). It is a must to leave models that are still dominant in our education system but have failed and to accept that education and school management is a professional field of the occupation, which requires various competences apart from "executive ability" (Simsek and Orucu, 2016).

Management processes that do not include the human dimension much in the organization may fail in managing a complex school structure and operation. School administrators should make radical changes in terms of understanding and putting into operation the management processes. While it is argued that school principals must have competences related to technical, human and conceptual subjects according to the traditional understanding, the dynamics of change in the internal and external environment have emphasised that these responsibilities should be developed and include leadership, communication, program development, learning and teaching processes, performance assessment skills (Kondakci and Zayim, 2013).

In a study that investigates the factors that cause a decrease in the motivation of primary school teachers, the student, parent and teacher-centered behaviours are expressed as follows: the normlessness of students, the fact that parents question the philosophy behind any behaviour of the teacher/necessary-unnecessary interference, the fact that the teaching profession is not sufficiently respected (Cerit, Kadioglu Ates and Yilmaz, 2017).

Nowadays, teachers need to build positive relationships with parents. Since the behaviours of teachers are constantly criticized when safe communication cannot be established between parents and teachers, the sense of belongingness of teachers can be negatively affected, and serious stress may occur. This increases the level of anxiety in teachers. It leads to the sense of not doing anything good in the teacher. Consequently, the need to protect themselves arises in teachers (Skaalvik and Skaalvik, 2011). The fact that the teacher does not effectively communicate with parents and leaving $\mathrm{him} / \mathrm{her}$ in a state of constant self-defence may affect his/her motivation negatively.

It is obvious that success in education is only possible with teachers who believe in their job, who are conscious, freed from concerns about any kind of creativity, in short, teachers with high spirits (Demirci, 2011).

Motivation is quite an important concept for education institutions. Education closely concerns the teacher's training programs at each level and not only the field of education management. Motivation, which appears very frequently in recent years in our country, has been examined variably in many studies conducted in the education literature abroad to date (Mansfield, Wosnitza and Beltman, 2012; Dinham and Scott, 1996; Ololube, 2006; Njiru, 2014; Perie and Baker, 1997; Wahab et al., 2014; Inayatullah and Jehangir, 2011; Nero, 1985; Losos, 2000; Frase and Sorenson, 1992; Kuvaas, 2006). The motivation of teachers is such a lionized phenomenon since it concerns teachers themselves, students, other colleagues and managers closely. The aim of this study is to examine the work motivation levels of primary school teachers. The problem sentence of the study was determined as "What is the work motivation level of primary school teachers?" The aims of the study are as follows:

1. What is the work motivation level of primary school teachers?

2. Does the work motivation of primary school teachers vary by gender?

3. Does the work motivation of primary school teachers vary by age?

4. Does the work motivation of primary school teachers vary by marital status?

5. What are the descriptive analysis results on the satisfaction factor of the work motivation of primary school teachers?

\section{Method}

There are four types of stages in which education studies are basically conducted. These are descriptive, causal, generalization and basic-theoretical-research. The descriptive research has two important branches. These are historical and contemporary research. While the historical one depicts "what it was", the contemporary descriptive research depicts "what is happening". The descriptive research is the first and main research action. It has great importance in understanding and increasing knowledge. Most education problems are descriptive (Balc1, 2015). In descriptive studies, the natural and social phenomena examined are not controlled. The researcher does not interfere with these phenomena. He does not prevent their flow. In other words, he does not put a new variable in the environment. He takes and processes the phenomenon as it is (Sonmez and Alacapinar, 2014). The research in question is a descriptive study. Descriptive statistics include techniques such as frequency, percentage, central tendency measures, variability measures and correlation coefficient that are used to describe the features of a group (Buyukozturk, 2007). The study was designed in the screening model. The screening model consists of research approaches that aim to describe a past or existing situation as it is (Karasar, 2003). Another advantage of the screening model is that it can be used without disturbing the existing order in the institution where the study is conducted and without creating administrative difficulties for the staff of the institution (Kaptan, 1998). The population of the study consists of primary school teachers and administrators working in state primary school institutions affiliated to the Ministry of National Education in Kuçukcekmece district. The sample of the study consisted of 343 primary school teachers and 28 
administrators selected using the disproportionate element sampling method from 14 state primary schools among primary school institutions in Kucukcekmece district. The simple random sampling method was used in the study. One of the basic types of unbiased sampling is simple random (unbiased) sampling (Christensen et al., 2015). As can be understood from its name, it is the sampling that consists of elements that have an equal chance of being selected (Arli and Nazik, 2003). In disproportionate element sampling, the number of the element types in the population that entered the sampling was completely left up to chance (Karasar, 2006). Sampling by chance (random) is like drawing lots. It is beneficial to select sampling by chance when the objects in the population are similar, change and are distributed on the same grounds, and they change in a similar way. Each has the same chance to be selected. Then the objects will be selected from everywhere in the population, and not from a single point of it (Kaptan, 1998).

Kucukcekmece is a district that receives immigrants, where people from different cultures live, and that reflects the socio-economic and cultural structure of Turkey. Furthermore, it is an easily accessible sample for the researchers. The area of education that the researchers investigated, Kucukcekmece is a place that is suitable for conducting research with its population of teachers. The number of schools in

Kucukcekmece district is 47 , with 2107 primary school teachers. 14 schools and 371 teachers were included in the sample, and $57 \%$ of the population was reached.

Table 1. Distribution of the participants by their age group

\begin{tabular}{lcc}
\hline Age & $\mathbf{N}$ & $\mathbf{\%}$ \\
\hline $21-25$ years & 21 & 5.7 \\
26-30 years & 51 & 13.7 \\
31-35 years & 89 & 24 \\
36-40 years & 97 & 26.1 \\
41 years and above & 113 & 30.5 \\
Total & 371 & 100 \\
\hline
\end{tabular}

According to Table 1, it is understood that the majority of the participants are from the groups of " 41 years and above" and "36-40 years". The ratio of the participants in the age group of $21-25$ years is $5.7 \%$, the ratio of the participants in the age group of $26-30$ years is $13.7 \%$, and the ratio of the participants in the age group of $31-35$ years is $24 \%$. The participants were divided into four groups during the analyses by combining the age range of 21-25 years and 26-30 years in order to ensure the equal distribution of the participants.

92.2\% (342 individuals) of the participants consist of primary school teachers, $2.4 \%$ (9 individuals) consist of school principals, and 5.4\% (20 individuals) consist of deputy principals. By gender, 59.6\% (221 individuals) of the participants that participated in the study are female, and $40.4 \%$ (150 individuals) are male.

The "Personal Information Form" and the "Work Motivation Scale" were used to collect data in the study. The "Work Motivation Scale" that is used to measure the work motivation of teachers was developed by Aksoy (2006). The five-point Likert-type scale was used in order to specify the frequency of each behaviour next to each item, and they were graded as "not satisfied at all - not satisfied - undecisive - satisfied - very satisfied" (1-5) from the least positive to the most positive. In the study of Yilmaz (2009), the factor loads of the items in the team cohesion dimension of the scale vary between 49 and .78, between .54 and .78 in the dimension of integration into work, between .59 and .81 in the dimension of commitment to the institution, and between .43 and .73 in the dimension of personal development. In this study, the Cronbach's alpha reliability coefficient of the work motivation scale was found as 0.897 , reliability studies were conducted for each of the sub-dimensions, and the alpha values were determined as .51 in the dimension of integration into work, .64 in the commitment to the organization, .68 in the team cohesion dimension, .61 in the personal development dimension, and 0.90 in total as a result of the factor analysis conducted. The value obtained showed that the scale was reliable.

In accordance with the aim of the study, the work motivation scores of the participants were comparatively investigated by their gender, age and marital status. Before making a comparison, the distribution of the work motivation scores by the independent variables was investigated by conducting the Kolmogorov-Smirnov, Shapiro-Wilk normality tests and calculating the skewness-kurtosis values. According to the results obtained, it was understood that the data are distributed quite closely by the groups. The homogeneity assumption of the variances was investigated with Levene's test, and it was understood that the assumption was fulfilled. After this stage, the analyses were performed using the parametric tests (independent sample t-test, one-way analysis of variance test). The minimum score that can be obtained from the scale is 18, and the maximum score is 90 . Accordingly, the scores between 18 and 42 were interpreted as the low level of motivation, scores between 43 and 66 were interpreted as the intermediate level of motivation, and scores between 67 and 90 were interpreted as the high level of motivation. The data were analysed using SPSS 20.0 package software. 
Table 2. Sub-Dimensions of the Work Motivation Scale

\begin{tabular}{ccc}
\hline Dimensions of the Scale & $\mathbf{X}$ & SD \\
\hline Team Cohesion & 9.05 & 2.65 \\
Integration into Work & 9.50 & 2.35 \\
Commitment to the Organization & 6.65 & 2.08 \\
Personal Development & 7.33 & 2.25 \\
\hline
\end{tabular}

The first sub-problem of the study is "What is the work motivation level of primary school teachers?". The descriptive information on the work motivation levels of teachers and scores they obtained from the Team Cohesion, Integration into Work, Commitment to the Organization and Personal Development dimensions that are the sub-dimensions of the scale was obtained by calculating the mean and standard deviation values.

Table 3. Analysis Results of the Work Motivation Scale

\begin{tabular}{lcllcc}
\hline & N & X & sd & Minimum score & Maximum score \\
\hline Total score of the scale & 371 & 41.84 & 10.32 & 18 & 90 \\
\hline
\end{tabular}

According to Table 3, the average of the scores obtained by the participants from the work motivation scale is 41.84 , and the standard deviation is 10.32 . The minimum score that can be obtained from the scale is 18 , and the maximum score is 90 . Accordingly, the scores between 18 and 42 were interpreted as the low level of motivation, scores between 43 and 66 were interpreted as the intermediate level of motivation, and scores between 67 and 90 were interpreted as the high level of motivation. In the light of this information, it can be said that the work motivation of the participants is at a low level. When the work motivation level of teachers and administrators was evaluated according to the sub-dimensions of the scale, it was observed to be at a high level in the sub-dimension of team cohesion and integration into work, and low in the sub-dimensions of commitment to the organization and personal development.

Table 4. The t-Test Table on Comparing the Scores Obtained by Primary School Teachers and Administrators from the Work Motivation Scale and Its Sub-Dimensions by Gender

\begin{tabular}{|c|c|c|c|c|c|c|}
\hline Dependent Variable & Gender & $\mathrm{N}$ & $\bar{X}$ & $\mathrm{Sd}$ & $\mathrm{t}$ & $\mathrm{p}$ \\
\hline \multirow[t]{2}{*}{ Work Motivation } & Female & 221 & 41.4389 & 9.70764 & -.923 & .357 \\
\hline & Male & 150 & 42.4467 & 11.16775 & & \\
\hline \multirow[t]{2}{*}{ Team Cohesion } & Female & 221 & 9.0498 & 2.51582 & -.036 & .971 \\
\hline & Male & 150 & 9.0600 & 2.85260 & & \\
\hline \multirow[t]{2}{*}{ Integration into Work } & Female & 221 & 9.3303 & 2.25518 & -1.758 & .080 \\
\hline & Male & 150 & 9.7667 & 2.47516 & & \\
\hline \multirow{2}{*}{$\begin{array}{l}\text { Commitment } \\
\text { Organization }\end{array}$} & Female & 221 & 6.6290 & 1.92540 & -.291 & .771 \\
\hline & Male & 150 & 6.6933 & 2.31408 & & \\
\hline \multirow[t]{2}{*}{ Personal Development } & Female & 221 & 7.1719 & 2.14843 & -1.657 & .098 \\
\hline & Male & 150 & 7.5667 & 2.39523 & & \\
\hline
\end{tabular}

The second sub-problem of the study is "does the work motivation level of primary school teachers and administrators vary by gender?" The t-test was applied to this end. According to the results, the work motivation levels of teachers do not vary by gender $(\mathrm{p}>0.05)$.

Table 5. ANOVA Test Table on the Variation of the Scores Obtained by Primary School Teachers and Administrators from the Work Motivation Scale and Its Sub-Dimensions by Age

\begin{tabular}{|c|c|c|c|c|c|}
\hline & & Sum of Squares & $\mathrm{Sd} \mathrm{I}$ & Mean of Squares & $\mathrm{F} \quad \mathrm{p}$ \\
\hline \multirow[t]{3}{*}{ Motivation } & Intergroup & 462.798 & 4 & 115.699 & 1.087 .362 \\
\hline & Intragroup & 38943.445 & 366 & 106.403 & \\
\hline & Total & 39406.243 & 370 & & \\
\hline \multirow[t]{3}{*}{ Team Cohesion } & Intergroup & 30.551 & 4 & 7.638 & 1.086 .363 \\
\hline & Intragroup & 2574.370 & 366 & 7.034 & \\
\hline & Total & 2604.922 & 370 & & \\
\hline \multirow[t]{3}{*}{ Integration into Work } & Intergroup & 21.841 & 4 & 5.460 & $.986 \quad .415$ \\
\hline & Intragroup & 2026.892 & 366 & 5.538 & \\
\hline & Total & 2048.733 & 370 & & \\
\hline \multirow[t]{3}{*}{ Commitment to the Organization } & Intergroup & 16.325 & 4 & 4.081 & .935 \\
\hline & Intragroup & 1597.514 & 366 & 4.365 & \\
\hline & Total & 1613.838 & 370 & & \\
\hline \multirow[t]{3}{*}{ Personal Development } & Intergroup & 33.835 & 4 & 8.459 & 1.673 .156 \\
\hline & Intragroup & 1850.386 & 366 & 5.056 & \\
\hline & Total & 1884.221 & 370 & & \\
\hline
\end{tabular}

Another sub-problem of the study is "Does the work motivation of primary school teachers vary by age?" To find an 
answer to this problem, the work motivation scores of the participants were examined by comparing them by the age groups. It was found out that the scores of the work motivation levels of teachers and the sub-dimensions of the scale (Team Cohesion $\mathrm{p}>0.05, \mathrm{~F}\left(_{4-366}\right)=1.086$, Integration into Work $\mathrm{p}>0.05, \mathrm{~F}(4-366)=0.986$, Commitment to the Organization $\mathrm{p}>0.05, \mathrm{~F}(4-366)=0.935$, Personal Development $\mathrm{p}>0.05, \mathrm{~F}(4-366)=1.673)$ do not vary by age. The age intervals of the participants were examined in four groups being 21-30, 31-35, 36-40, and 41 years and above.

Table 6. Independent Sample t-Test Results on the Comparison of the Scores Obtained by Primary School Teachers and Administrators from the Work Motivation Scale and Its Sub-Dimensions by Marital Status

\begin{tabular}{|c|c|c|c|c|c|c|}
\hline $\begin{array}{l}\text { Dependent } \\
\text { Variable }\end{array}$ & Marital Status & $\mathrm{N}$ & $\bar{X}$ & $\mathrm{Sd}$ & $\mathrm{t}$ & $\mathrm{p}$ \\
\hline \multirow[t]{2}{*}{ Work Motivation } & Single & 68 & 41.8382 & 9.72550 & -.007 & .340 \\
\hline & Married & 303 & 41.8482 & 10.46423 & & \\
\hline \multirow[t]{2}{*}{ Team Cohesion } & Single & 68 & 9.0000 & 2.67102 & -.185 & .774 \\
\hline & Married & 303 & 9.0660 & 2.65367 & & \\
\hline \multirow{2}{*}{$\begin{array}{l}\text { Integration into } \\
\text { Work }\end{array}$} & Single & 68 & 9.7353 & 2.25016 & .886 & .271 \\
\hline & Married & 303 & 9.4554 & 2.37617 & .917 & \\
\hline \multirow{2}{*}{$\begin{array}{l}\text { Commitment to } \\
\text { the Organization }\end{array}$} & Single & 68 & 6.5882 & 2.03136 & -.291 & .271 \\
\hline & Married & 303 & 6.6700 & 2.10408 & & \\
\hline \multirow{2}{*}{$\begin{array}{l}\text { Personal } \\
\text { Development }\end{array}$} & Single & 68 & 7.1618 & 2.17592 & -.686 & .336 \\
\hline & Married & 303 & 7.3696 & 2.27614 & & \\
\hline
\end{tabular}

Another sub-problem of the study is "does the work motivation level of primary school teachers and administrators vary by marital status?" The work motivation scores of the participants were investigated by comparing them according to their marital status in order to find an answer to this problem. It was observed that the work motivation level scores of primary school teachers and administrators and scale sub-dimensions (Team Cohesion, Integration into Work, Commitment to the Organization, and Personal Development scores) do not vary by marital status.

Table 7. Descriptive analysis results of the work motivation of primary school teachers related to the satisfaction factors

\begin{tabular}{|c|c|c|c|c|c|c|}
\hline & & $\mathrm{N}$ & Minimum & Maximum & $\overline{\mathbf{X}}$ & $\mathrm{Sd}$ \\
\hline M1 & Working in this institution & 371 & 1.00 & 5.00 & 1.7628 & .74458 \\
\hline M2 & $\begin{array}{l}\text { The respect I receive from } \\
\text { society because of my duty }\end{array}$ & 371 & 1.00 & 5.00 & 2.6011 & 1.13775 \\
\hline M3 & $\begin{array}{l}\text { The physical working } \\
\text { environment at school }\end{array}$ & 371 & 1.00 & 5.00 & 2.3558 & 1.03589 \\
\hline M4 & Harmony with my colleagues & 371 & 1.00 & 5.00 & 1.8005 & .71893 \\
\hline M5 & Additional payment system & 371 & 1.00 & 5.00 & 3.3450 & 1.14353 \\
\hline M6 & $\begin{array}{l}\text { Being appreciated and the } \\
\text { sense of success I have }\end{array}$ & 371 & 1.00 & 5.00 & 2.4825 & .97902 \\
\hline M7 & $\begin{array}{l}\text { Performance evaluation } \\
\text { system in my organization }\end{array}$ & 371 & 1.00 & 5.00 & 2.5957 & .99913 \\
\hline M8 & $\begin{array}{l}\text { The income I gain from my } \\
\text { institution }\end{array}$ & 371 & 1.00 & 5.00 & 2.7547 & 1.07387 \\
\hline M9 & $\begin{array}{l}\text { Harmony between the } \\
\text { administrators }\end{array}$ & 371 & 1.00 & 5.00 & 1.9596 & .87053 \\
\hline M10 & $\begin{array}{l}\text { Professional training and } \\
\text { development opportunities }\end{array}$ & 371 & 1.00 & 5.00 & 2.5768 & .99534 \\
\hline M11 & $\begin{array}{l}\text { The degree at which I can use } \\
\text { my creativity }\end{array}$ & 371 & 1.00 & 5.00 & 2.2803 & .88965 \\
\hline M12 & $\begin{array}{l}\text { The importance attributed to } \\
\text { team-work }\end{array}$ & 371 & 1.00 & 5.00 & 2.3127 & .88490 \\
\hline M13 & $\begin{array}{l}\text { The amount of responsibility } \\
\text { given }\end{array}$ & 371 & 1.00 & 5.00 & 2.3235 & .88101 \\
\hline M14 & $\begin{array}{l}\text { The social activities performed } \\
\text { Total }\end{array}$ & $\begin{array}{l}371 \\
371\end{array}$ & 1.00 & 5.00 & 2.3827 & .96933 \\
\hline
\end{tabular}

According to the descriptive analysis results on the satisfaction factors of the work motivation of primary school teachers and administrators, it was found out that primary school teachers and administrators stated that they were not satisfied with "Working in this institution $(\overline{\mathbf{x}}=1.7628)$, harmony with colleagues $(\overline{\mathbf{x}}=1.8005)$, harmony between the administrators $(\overline{\mathbf{x}}=1.9596)$ ". The items that primary school teachers and administrators were most satisfied with are "The additional payment system $(\overline{\mathbf{x}}=3.3450)$, the income I gain from my institution $(\overline{\mathbf{x}}=2.7547)$, and the respect I receive from society because of my duty ( $\overline{\mathbf{x}}=2.6011)$ ".

\section{Conclusion, Discussion and Suggestions}

The following results were achieved in accordance with the findings obtained from the analysis of the data collected in the study: 
1. Another sub-problem of the study is "What is the work motivation level of primary school teachers?" The average of the scores obtained by the participants from the work motivation scale is $\overline{\mathrm{X}}=41.84$, and the standard deviation is 10.32 . In the light of this information, it can be said that the work motivation of the participants is low. Upon assessing the work motivation level of teachers and administrators according to the sub-dimensions of the work motivation scale, it is observed to be high in the team cohesion and integration into work sub-dimensions, and low in the commitment to the organization and personal development sub-dimensions.

2. "Does the work motivation level of primary school teachers and administrators vary by gender?" The work motivation scores of the participants were investigated by being compared according to gender to find an answer to this problem. It was determined that the average work motivation scores do not vary significantly by gender ( $p>0.05$ ). It was understood that the work motivation levels of female and male participants are quite close to one another.

3. Another sub-problem of the study is "Does the work motivation level of primary school teachers and administrators vary by age?" The work motivation scores of the participants were comparatively investigated by the age groups to find an answer to this problem. It was observed that the work motivation level scores of primary school teachers and administrators and scale sub-dimensions (Team Cohesion $p>0.05, F(4-366)=1.086$, Integration into Work $p>0.05, F(4-366)=$ 0.986, Commitment to the Organization $\mathrm{p}>0.05, \mathrm{~F}(4-366)=0.935$, and Personal Development $\mathrm{p}>0.05, \mathrm{~F}(4-366)=1.673)$ scores do not vary by the age group. The work motivation levels of the participants from different age groups are at a similar level.

4. Another sub-problem of the study is "Does the work motivation level of primary school teachers and administrators vary by marital status?" The work motivation scores of the participants were comparatively investigated by marital status to find an answer to this problem. The work motivation level scores of primary school teachers and administrators and scale sub-dimensions (Team Cohesion, Integration into Work, Commitment to the Organization and Personal Development) scores do not vary by marital status $(\mathrm{p}>0.05)$. It was understood that the work motivation of single and married participants is at a similar level.

5. According to the descriptive analysis results on the satisfaction factors of the work motivation of primary school teachers and administrators, teachers and administrators stated that they were not satisfied with "Working in this organization $(\overline{\mathbf{x}}=1.7628)$, harmony with the colleagues $(\overline{\mathbf{x}}=1.8005)$, and harmony between the administrators $(\overline{\mathbf{x}}$ $=1.9596)$ ". The items that primary school teachers and administrators were most satisfied with are "the additional payment system $(\overline{\mathbf{x}}=3.3450)$, the income I gain from my institution $(\overline{\mathbf{x}}=2.7547)$, and the respect I receive from society because of my duty $(\overline{\mathbf{x}}=2.6011)$ ".

The average of the scores obtained by the participants from the work motivation scale is $\overline{\mathrm{X}}=41.84$, and standard deviation 10.32. In the light of this information, it can be said that the work motivation of the participants is low in general. The items that reduce work motivation are items such as working in this institution $(\overline{\mathbf{x}}=1.7628)$, harmony with the colleagues ( $\overline{\mathbf{x}}=1.8005)$, and harmony between the administrators $(\overline{\mathbf{x}}=1.9596)$."

There are many studies on work motivation in the literature. Erturk (2014) achieved the result that the general perception of teachers of work motivation is at the "intermediate" level. In the study of Y1lmaz (2009), the work motivation level of teachers is high. As a result of the study conducted by Tanriverdi (2007), it was found out that the work motivation level of teachers is high. Buyukses (2010) found that the average scores obtained by teachers from the statements related to work motivation varied between 2.03 and 4.68. The findings of the study conducted by Erturk (2014), Y1lmaz (2009), Tanriverdi (2007) and Buyukses (2010) and the work motivation level results of this study do not match. It can be said that the reason for this difference is the branch and number of the source groups, time factor, attitude of the school administration, additional payment system, attitude of parents, the level of respectability of the profession in the society, the physical working environment at school, and the gains provided by the institution. Bennell and Akyeampong (2007), who investigated the work motivation levels of teachers in Asian and African countries, found that the work motivation levels of primary school teachers were quite low. In the study conducted by Emirbey (2017), the opinions of teachers on their own work motivation were found to be at a medium level with "Partially satisfied". According to the researcher, since the work motivation level of teachers is found to be low, the reasons for this low motivation can be investigated, and precautions can be taken.

The work motivation levels of primary school teachers and administrators do not vary by gender, age and marital status. The work motivation scores of the participants were investigated by being compared by gender. It was found out that the average work motivation scores do not vary significantly by gender, and the work motivation levels of female and male participants are quite close to one another. This result is in parallel with the findings of the studies conducted by Emirbey (2017), Aksel (2016), Tecer (2011), Bektas (2012), Canpolat (2011), Aksoy (2006), Recepoglu (2011), Buyukses (2010), Erturk (2014) and Tanriverdi (2007). However, there are also studies that are not in parallel with the findings of the study. In the study, Polat (2010) found that there was a significant difference in the perceptions of teachers in the internal 
motivation dimension by gender, and the internal motivation levels of female teachers were higher compared to male teachers.

Another sub-problem of the study is "does the work motivation level of primary school teachers and administrators vary by age?". The work motivation scores of the participants were comparatively investigated by their age groups to find an answer to this problem. It was determined that the work motivation of the participants in different age groups was at a similar level. In the studies of Recepoglu (2011), Tanriverdi (2007) and Ozgun (2008), work motivation scores vary by the variable of age. On the other hand, Yllmaz (2009), Guven (2007), Tiryaki (2008), Tanriverdi (2007), Everett (1988), Pennington (1997), Smith (1999) and Oades (1983) also determined that the motivation level of teachers does not differ by the variable of age.

Another sub-problem of the study is "Does the work motivation level of primary school teachers and administrators vary by marital status?". The work motivation scores of the participants were comparatively investigated by marital status to find an answer to this problem. It was understood that the average of the work motivation scores does not vary significantly by marital status, and the work motivation of single and married participants is at a similar level. In the study of Toker (2007), it was determined that there is no difference between the job satisfaction levels of married and single employees. On the other hand, in the studies conducted by Kaynak (2016), it was understood that job satisfaction does not vary by the status of being single or married.

According to the descriptive analysis results on the satisfaction factors of the work motivation of primary school teachers and administrators, it was determined that primary school teachers and administrators were not satisfied with "Working in this institution", "Harmony with my colleagues", "Harmony between the administrators". The items that primary school teachers and administrators were most satisfied with were specified as the "additional payment system, the income I gain from my institution, and the respect I receive from society because of my duty."

In future studies, the work motivation of branch teachers working at primary schools in addition to primary school teachers can be measured. Other variables were not addressed in the present study that measures age, gender and marital status. In future studies, whether work motivation varies according to variables such as having a child, the type of school graduated, educational level, total monthly income, the state of having a child and the number of children, professional seniority, and the years that teachers spent in the relevant institution, etc. can be determined. The relevant study is a quantitative study. A qualitative study can be conducted by asking the primary school teachers whose work motivation has been found to be low about the factors affecting their motivation. The MNE can take measures that increase the work motivation of primary school teachers. By ensuring coordination between university and primary school, it can be ensured that primary school teachers who are in charge meet academicians working at relevant universities, take precautions and cooperate with them at the points of fulfilling them by themselves regarding the negative effects that affect their work motivation.

Studies conducted on human beings have shown that people produce more when they are motivated. The reasons for motivation that ensures productivity can be quite variable since they depend on both the environment, individual and relationships. According to the researchers, the actual motivation is one's intrinsic motivation because intrinsic motivation is more permanent in the individual (Bakioglu and Guner, 2016). It is especially important to develop the intrinsic motivation of pre-service teachers for the employment of teachers (O'Brien \& Goddard, 2006). Intrinsic motivation means a desire or wish to know, understand and learn (Spittle, Jackson, Casey; 2009). Precautions that increase the intrinsic motivation of pre-service primary school teachers can be taken with the cooperation of the Higher education institution and the Ministry of National Education. Mixed studies in which qualitative and quantitative studies are blended can be conducted. Commissions can be established at the district, provincial and school level to increase teacher motivation. The Ministry of National Education and school administrators can conduct scientific activities in the form of panel, symposium and conversation that emphasise the place and importance of teachers in the society in order to increase the respectability of the teaching profession. Teachers can be financially and morally supported for the opportunities of professional training and development. Any kind of innovation related to education can be shared with the entire education community. Teachers that participate in scientific studies and exhibit different performances can be rewarded. The study can be repeated in different regions and cities of Turkey, and with primary school teachers working in different districts of Istanbul. Therefore, a comparison can be made. Furthermore, the motivation of teachers can be investigated according to different demographic features. The relationship between work motivation and different variables can also be measured. Whether work motivation varies by variables such as job satisfaction, life satisfaction, burnout, alienation from work, school culture and political discrimination can be investigated.

\section{References}

Ada, S., \& Baysal, Z. N. (2012). Turkish Education System and Effective School Management - (2. edition). Ankara: Pegem. 
Adair, J. (2013). Effective Motivation. Salih Uyan (translated). Ankara: Babiali.

Addison, R., \& Brundrett, M. (2008). Motivation and de-motivation of teachers in primary schools: the challenge of change. International Journal of Primary, Elementary and Early Years Education, 36(1), 79-94.

Aksel, N. (2016). The Relationship Between the Transformational Leadership Behavior of the Secondary School Principals and the Motivation of Teachers (Samsun Case). Unpublished master's thesis, Ondokuz May1s University Education Science Institute, Sakarya.

Aksoy, H. (2006). The Impact of Organizational Climate on Motivation, Unpublished master's thesis, Marmara University, Social Sciences Institute, İstanbul.

Arli, M., \& Nazik, H. (2003). Introduction to Scientific Research- (2. edition). Ankara: Gazi.

Arslan, M. C. (2012). Motivation of Primary School Principals' Democratic Attitudes and Behaviors and Their Impact on Student Success, Unpublished master's thesis, Gaziantep University Social Sciences Institute.

Ates, H., Yildiz, B., \& Yildiz, H. (2012). Can Herzberg's Two Factor Theory Explain the Motivation Perceptions of Teachers in Public Schools? An Empirical Research, Knowledge Economy and Management Magazine, VII(II), 147-162.

Ayaydin, M., \& Tok, M. (2015). Investigation Class Teachers' Opinion About Motivation Factors (Gaziantep Sample), Turkish Studies - International Periodical for the Languages, Literature and History of Turkish or Turkic-, ISSN: 1308-2140, 10(11), Summer 2015, Ankara/Turkey. 187-200. https://doi.org/10.7827/TurkishStudies.8530

Aydin B. (2004). Education and Turkish Education System in the 21st Century. İstanbul: Dem.

Aydin, A. H. (2011). Management Science (4. edition). Ankara: Seckin.

Bakioglu, A., \& Guner, H. (2016). Motivation and Conflict. Aysen Bakioglu (Editor), Turkish Education System and School Management (pages.73-96). Ankara: Nobel.

Balci, A. (2015). Research Methods, Techniques and Principles in Social Sciences (11. edition). Ankara: Pegem.

Bektas, A. (2012). The Impact of Managerial Job Satisfaction and Motivation Levels on the Meaning of Life Level, Unpublished Master's Thesis, Maltepe University Social Sciences Institute, İstanbul.

Bennell, P., \& Akyeampong, K. (2007). Teacher Motivation in Sub-Saharan Africa and South Asia. Department for International Development Researching the Issues, 71, 1-114.

Bishay, A. (1996). Teacher Motivation and Job Satisfaction: A Study Employing the Experience Sampling Method. Journal of Undergraduate Sciences Psycholog, 3, 147-154.

Buluc, B. (2013). Organizational Culture and Climate. Servet Ozdemir (Editor), Theory and Practice in Educational Administration (pages. 101-130). Ankara: Pegem.

Bursalioglu, Z. (2014). Theory and Practice in Educational Administration (12. edition). Ankara: Pegem.

Buyukses, L. (2010). Factors Affecting Teacher Motivation in Business Environment, Unpublished Master's Thesis, Suleyman Demirel University Social Sciences Institute, Isparta.

Can, N. (Ed.) (2013). Educational Management in Theory and Practice (2. edition). Ankara: Pegem.

Canpolat, C. (2011). Relations Between Teacher Motivation and Organizational Commitment by Applying Teacher Career Steps, Unpublished Master's Thesis, Firat University Education Science Institute, Elazı̆̆.

Celik, V., \& Gomleksiz, M. N. (2000). A Critical Examination of Globalization and its Effects on Education. Firat University Social Sciences Journal, 10(2).

Celikten, M., Sanal, M., \& Yeni, Y. (2005). Teaching profession and its characteristics. Erciyes University Social Sciences Institute Journal, 19(2).

Cemaloglu, N. (2002). The role of the school administrator in improving teacher performance. National Education Journal, 152-163.

Cerit, Y., Kadioglu, A. H., \& Yilmaz, P. (2017). Investigation of Factors Affecting Job Motivation Perceptions of Class Teachers-, YEAUK 2017 International Research on Education and Applications in Higher Education in Higher Education, 19-20 May, 2017 İstanbul.

Christensen, L. B., Johnson, R. B., \& Turner, L. A. (2015). Research methods design and analysis (2. edition) Ahmet Aypay (Translated). Anı: Ankara.

Cicek, S. A. (2015). School organization and management. Hasan Basri Memduhoglu and Kursad Yilmaz (Editors). 
Turkish education system and school management (7. Edition). (Pages 159-190). Ankara: Pegem.

Demirci, O. (2011). Differences in the Rights of Employees of Contractual and Employed Teachers Working in Primary Schools and Work Motivation, Unpublished Master's Thesis, Usak University, Social Science Institute.

Dinham, S., \& Scott, C. (1996). Teacher satisfaction, motivation and health: Phase one of the teacher 2000 project. Presented at the Annual Meeting of the American Educational Research Association. EDRS Availability: Microfiche.

Dönmez, B. (2013). Motivation. Servet Ozdemir (Ed.) Theory and Practice in Educational Administration. Ankara: Pegem.

Duren, Z. (2002). Management over 2000 years. İstanbul: Alfa.

Emirbey, A. R. (2017). The Relationship Between School Administrators' Ethical Leadership Behavior and Teacher Motivation (Denizli Province Çivril District Example). Unpublished Master's Thesis, Uşak University.

Eren, E. (2010). Organizational Behavior and Management Psychology. (12. edition). İstanbul: Beta.

Erturk, R. (2014). The Relationship Between Teachers' Motivation and Organizational Commitment (The Case of Bolu Province). Unpublished Master's Thesis, Abant Izzet Baysal University Education Science Institute, Bolu.

Everett, G. B. (1988). A study of the relationship between principal's leadership style and the level of motivation of the teaching staff. Unpublished Doctoral dissertation, Tennessee State University Graduate School, Tennessee.

Fidan, N. (2012). Learning and teaching in school. (3. edition). Ankara: Pegem.

Frase, L. E., \& Sorenson, L. (1992). Teacher motivation and satisfaction: Impact on participatory management. Nassp Bulletin, 76(540), 37-43. https://doi.org/10.1177/019263659207654007

Genc, N. (2005). Management and organization. Ankara: Seckin.

Gokay, M., \& Ozdemir, Ş. S. (2010). Factors Affecting the Motivations of Visual Arts (Painting-Business) Teachers. Social Science Journal, 26, 187- 200.

Gunes, H. (2016). Education Management. Ankara: Nobel.

Gungor, S. M. (2016). Ethics in school management. Ahmet Aypay (Editor). Education management and inspection of the Ministry of Education in Turkey. (pages 253-278). Ankara: Pegem.

Guven, A. (2007). The effects of public administrators' behavior styles on staff motivation: An application on teachers working in Tokat provincial national education directorate. Unpublished Master's Thesis, Gazi Osman Pasa University Social Science Institute, Tokat.

Hanks, K. (1999). Motivating People. İstanbul: Alfa.

Inayatullah, A, \& Jehangir, P. (2012). Teacher's job performance: The role of motivation. Abasyn Journal of Social Sciences, 5(2), 78-99.

Kadioglu, A. H., \& Tinaztepe, A. G. (2016). Investigation of Metaphorical Perceptions of Primary School Teachers about Resilience-. ICQH 2016 International Quality Congress in Higher Education, 23 December 2016, Sakarya.

Kaptan, S. (1998). Scientific research and statistics techniques (11. edition). Ankara: Tekisik.

Karakose, T., \& Kocabaş, İ. (2006). The Effects of Teachers' Expectations on Job Satisfaction and Motivation in Private and State Schools, Theory and Practice in Education, 2(1), 3-14.

Karasar, N. (2003). Scientific Research Method (12. edition). Ankara: Nobel.

Karasar, N. (2006). Scientific Research Method. Ankara: Nobel.

Kaynak, E. (2016). Job Satisfaction Motivation Relations in Generation Y employees in Turkey, Unpublished Master's Thesis, Dogus University Social Science Institute, İstanbul.

Kilinç, A. Ç., \& Ogdem, Z. (2013). The concept of school as a professional learning society. Servet Ozdemir (Editor). Theory and Practice in Educational Administration (pages 333-349). Ankara: Pegem.

Kondakci, Y., \& Zayim, M. (2013). Management processes. Servet Ozdemir (Editor). Theory and Practice in Educational Administration (Pages 9-62). Ankara: Pegem.

Kurt, T. (2005). Herzberg's Two Factor Motivation Theory in Terms of Teachers Motivation. Gazi University Education Science Institute Ankara.

Kuvaas, B. (2006). Work performance, affective commitment, and work motivation: The roles of pay administration and 
pay level. Journal of Organisational Behaviour, 27, 365-385. https://doi.org/10.1002/job.377

Losos, L. W. (2000). Comparing the motivation levels of public, private and parochial high school teachers. Unpublished Doctoral dissertation, Saint Louis University. UMI Microform 9973372.

Mansfield, C., Wosnitza, M., \& Beltman, S. (2012). Goals For Teaching: Towards A Framework For Examining Motivation Of Graduating Teachers. Australian Journal Of Educational \& Developmental Psychology, 12, 21-34.

Nero, A. B. (1985). Intrinsic/Extrinsic motivational factors and perceived need deficiencies as a function of job level in an urban school district. Unpublished Doctoral dissertation, Memphis State University.

Njiru, L. M. (2014). Job Satisfaction and Motivation among Teachers of Kiharu District in Kenya. Mediterranean Journal of Social Sciences, 5(5), 135-152. https://doi.org/10.5901/mjss.2014.v5n5p135

O'Brien, P., \& Goddard, R. (2006). Beginning teachers: easing transition to the classroom. Australian Educational Leader, 28, 28-31.

Oades, C. D. (1983). Relationship of teacher motivation and job satisfaction. Unpublished Doctoral dissertation, University of Manitoba, Canada.

Oklay, E. (2016). Leadership skills and competence areas of school administrators. Ahmet Aypay (Editor). Inspectorate of education in educational management and selection appointment and training in Turkey (pages 87-110). Ankara: Pegem.

Ololube, P. O. (2005). Teachers Job Satisfaction and Motivation for school effectiveness: An assessment. Masters of Business Administration Thesis. University of Halsmti Finland.

Ozdemir S., Yalin, H. İ., \& Sezgin, F. (2008). Introduction to educational science (6. edition). Ankara: Nobel.

Ozdemir, M. (2015). Management processes. Uğur Akın (Editor). Turkish Education System and School Management (Pages 153-178). Ankara: Pegem.

Pasathang, S., Tesaputa, K., \& Sataphonwong, P. (2016). Teachers' Performance Motivation System in Thai Primary Schools International Education Studies. Published by Canadian Center of Science and Education, 9(7).

Pennington, P. W. (1997). Principal leadership and teacher motivation in secondary schools. Unpublished Doctoral dissertation, Tennessee State University Graduate School, Tennessee May 2013, 21(2).

Perie, M., \& Baker, D. P. (1997). Job Satisfaction Among America's Teachers: Effects of Workplace Conditions, Background Characteristics, and Teacher Compensation. https://nces.ed.gov/pubs97/97471.pdf

Polat, S. (2010). The Relationship between Teacher Perceptions and Teacher Motivations of Administrative Power Sources Used by Pre-School Administrators. Unpublished Master's Thesis, Yeditepe University Social Science Institute, İstanbul.

Recepoglu, E. (2011). Analysis of Teachers' Job Motivations in Terms of Different Variables. Kastamonu Education Journal, 21(2), 576-588.

Robbins, S. P. (2000). Organizational Behavior (9th Edition). New Jersey: Prentice Hall.

Sezgin, F. (2013). School as a social system. Servet Ozdemir (Editor). Institution and practice in educational administration (pages 63-100). Ankara: Pegem.

Shinn, G. (2010). The Miracle of Motivation. Ulaş Kaplan (Translated). İstanbul: Sistem.

Shukr, I. Qamar, K., \& Hassan, A. U. (2016). Faculty's Perceptıon Of Level Of Teacher's Motıvatıon, Army Medical College/ National University of Medical Sciences (NUMS) Rawalpindi, Pakistan, Pak Armed Forces Med J 2016, 66(6), 784-789.

Simsek H., \& Orucu, D. (2016). An overview of the training of school managers in the world and Turkey. Ahmet Aypay (Editor). Inspectorates of education in educational leadership in Turkey and selection, appointment and training. Ankara: Pegem.

Skaalvik, E. M., \& Skaalvik, S. (2011). Teacher job satisfaction and motivation to leave the teaching profession: Relations. Teaching and Teacher Education, 27, 1029-1038. https://doi.org/10.1016/j.tate.2011.04.001

Smith, T. M. (1999). A study of the relationship between principal's leadership style and- teacher motivation: The teachers' perspective. Unpublished Doctoral dissertation, Georgia State University College of Education, Georgia.

Sonmez, V., \& Alacapinar, F. (2014). Scientific research methods. Ankara: Ani.

Spittle, M., Jackson, K., \& Casey, M. (2009). Applying self-determination theory to understand the motivation for 
becoming a physical education teacher. Teaching and Teacher Education, 25, 190-197. https://doi.org/10.1016/j.tate.2008.07.005

Sulak, H. (2012). School experience and teaching practice (Ed.) (3. edition). Konya: Literaturk.

Tanriverdi, S. (2007). A case study on the relationship between the motivation of foreign language teachers of participatory school cultures and work motivation. Unpublished Master's Thesis, Yeditepe University Social Science Institute, İstanbul.

Tas, S. (2005). Factors Affecting the Motivation of Classroom Teachers, Unpublished Master's Thesis, Selcuk University Social Science Institute, Konya.

Tecer, O. (2011). The Effect of Teachers' Internal Motivation Job Satisfaction Levels of School Supervisors Made by Primary Education Inspectors, Unpublished Master's Thesis, Ahi University Social Science Institute, Kirsehir.

Terzi, A. R., \& Kurt, T. (2005). The Impact of Managerial Behaviors of Elementary School Principals on Teachers' Organizational Commitment, Milli Education Journal, 33(166), 98-111.

Tiryaki, A. (2008). An Application for Modern Leadership Approaches and Employee Motivation in Business, Unpublished Master's Thesis, Yildiz Teknik University Social Science Institute, İstanbul.

Toker, B. (2007). The effects of demographic variables on job satisfaction: An application for five and four star hotels in İzmir. Dogus University Journal, 8(1), 92-107.

Ultanır, G. (2007). Self-assessment assessment profile of primary schools. Ayla Oktay and Ozgul Polat Unutkan (Eds.) An Overview of the Age of Primary Education. İstanbul: Morpa.

Unal S., \& Ada, S. (1999). Introduction to Teaching Profession. İstanbul: Marmara University Pub.

Unsar, A. S. (2011). The Effect of Motivation on Leaning Behavior. A field study. Academic Overview, 25, 1-15.

Wahab, J. A., Fuad, C. F. M., Ismail, H., \& Majid, S. (2014). Headmasters' transformational leadership and their relationship with teachers' job satisfaction and teachers' commitments. International Education Studies, 7(13), 40-48. https://doi.org/10.5539/ies.v7n13p40

Yalcin, H., \& Korkmaz, M. (2013). Motivation Situations of Preschool Teachers, International Social Research Journal,, 6(26), 1045-1061.

Yavuz, C., \& Karadeniz, C. B. (2009). The Effect of Classroom Teacher Motivation on Job Satisfaction, International Social Research Journal, $2,9$.

Yilmaz, A., \& Ceylan, Ç. B. (2011). Relationship between Primary School Administrators 'Leadership Behavior Levels and Teachers' Job Satisfaction. Educational Management in Theory and Practice, 17(2), 277-394.

Yilmaz, F. (2009). The influence of teachers' cultural motivation on organizational culture in educational organizations, Unpublished Master's Thesis, Selcuk University Social Science Institute, Konya.

\section{Copyrights}

Copyright for this article is retained by the author(s), with first publication rights granted to the journal.

This is an open-access article distributed under the terms and conditions of the Creative Commons Attribution license which permits unrestricted use, distribution, and reproduction in any medium, provided the original work is properly cited. 